\title{
PENGARUH PENDIDIKAN GIZI DENGAN MEDIA SOSIAL TERHADAP PERSEPSI BODY IMAGE REMAJA
}

\author{
Ravi Masitah ${ }^{1}$, Eti Poncorini Pamungkasari ${ }^{2}$, Suminah $^{3}$ \\ ${ }^{1}$ Program Studi Ilmu Gizi, Fakultas Ilmu Kesehatan, Sains, dan Teknologi Universitas Dhyana Pura. \\ ${ }^{2}$ Program Studi Kedokteran, Fakultas Kedokteran, Universitas Sebelas Maret Surakarta. \\ ${ }^{3}$ Program Studi Penyuluhan dan Komunikasi Pertanian, Fakultas Pertanian, Universitas Sebelas Maret Surakarta. \\ Email : masitahravi@gmail.com
}

\begin{abstract}
ABSTRAK
Body image negatif sangat umum terjadi pada masa remaja dan mempunyai dampak buruk bagi kesehatan seperti meningkatnya resiko rendah diri, depresi, gangguan aktivitas fisik dan pola makan. Pendidikan gizi adalah salah satu intervensi yang dapat dilakukan untuk mengatasi permasalahan tersebut. Media sosial telah menjadi bagian kehidupan remaja sehingga dapat digunakan sebagai media pendidikan. Pendidikan gizi dengan media sosial dapat dengan mudah diakses dan tidak terbatas pada ruang dan waktu. Tujuan penelitian adalah menganalisis pengaruh pendidikan gizi dengan media sosial terhadap persepsi body image remaja. Jenis penelitian Quasi Experimental Design dengan rancangan Nonequivalent Control Group. Subjek penelitian siswa kelas XI IPA SMAN 1 Wates dan SMAN 1 Lendah masing-masing 42 remaja. Penentuan dengan purposive sampling. Penelitian dilaksanakan selama I bulan yaitu sebanyak 3 kali seminggu. Analisis data menggunakan uji Wilcoxon dengan SPSS. Hasil uji Wilcoxon menunjukkan pendidikan gizi dengan media sosial mempengaruhi persepesi body image remaja $(p=0.008)$. Ada pengaruh pendidikan gizi dengan media sosial terhadap persepsi body image remaja. Penggunaan media sosial yang tepat dapat membentuk persepsi body image positif pada remaja.
\end{abstract}

Kata Kunci : Media sosial, persepsi body image, remaja

\section{ABSTRACT}

Negative body image was very common in adolescence and had the impact of bad for health such as increased risk of low self-esteem, depression, impaired physical activity and eating patterns. Nutrition education was one of the interventions that can be done to overcome these problems. Social media had become a part of teenage life so it could be used as a medium of education. Nutrition education with social media could be easily accessed and it was not limited in time and space. The aim of this research was to analyze the effect of nutrition education with social media against the perception of body image teenagers. This type of research was Quasi Experimental Design with Nonequivalent Control Group. The subjects were students of Class XI IPA SMAN 1 Wates and SMAN 1 Lendah each of 42 teenagers, purposive sampling with determination. The research was carried out during a month that is as much as 3 times a week. It used the Wilcoxon test data analysis with SPSS. The Wilcoxon test results showed nutrition education with social media affect teen body image persepesi $(p=0.008)$. There was influence of the nutrition education with social media against perception of body image teenagers. The use of social media made positive body image perception in teenagers.

Keyword : Social media, the perception of body image, teenager

\section{PENDAHULUAN}

Masa remaja disebut dengan masa pubertas (Christianti dan Khomsan, 2012). Proses tersebut ditandai dengan munculnya karakteristik seksual sekunder (Faria et al., 2013). Data demografi menunjukkan bahwa terdapat 1,2 milyar remaja (usia 10-19 tahun) atau 18\% dari populasi dunia dan lebih dari setengah remaja hidup di Asia. Indonesia memiliki populasi remaja usia 10-19 tahun mencapai 43 juta jiwa atau $18 \%$ dari 269 juta penduduk Indonesia (UNICEF, 2012).

Gizi yang baik dapat meningkatkan kesehatan yang optimal, pertumbuhan dan perkembangan intelektual dan mencegah masalah kesehatan pada remaja (Erturgut dan Erturgut, 2010). Berdasarkan data Riskesdas tahun 2013, prevalensi kurus pada remaja usia $13-15$ tahun adalah $11,1 \%$ terdiri atau $3,3 \%$ sangat kurus dan $7,8 \%$ kurus sedangkan prevalensi gemuk $18,8 \%$, terdiri dari gemuk sebesar $10,8 \%$ dan sangat gemuk (obesitas) $8,8 \%$. Prevalensi kurus pada remaja usia 16-18 tahun secara nasional sebesar 9,4\% (1,9\% sangat kurus dan $7,5 \%$ kurus) sedangkan prevalensi gemuk sebanyak 7,3\% terdiri dari 5,7\% gemuk dan 1,6\% obesitas (Kemenkes RI, 2013).

Daerah Istimewa Yogyakarta pada tahun 2013 adalah salah satu provinsi dengan prevalensi 
sangat gemuk (obesitas) pada remaja usia 16-18 tahun di atas prevalensi nasional yaitu 2,6\%. Selain itu masih terdapat masalah gizi seperti gemuk $(7,2 \%)$, kurus $(8,1 \%)$ dan sangat kurus $(1,2 \%)$, sedangkan remaja usia 13-15 tahun dengan status gizi sangat gemuk (obesitas) (4,2\%), gemuk $(6,7 \%)$, kurus $(4,9 \%)$ dan sangat kurus $(2,4 \%)$. Kulon Progo merupakan Kabupaten dengan masalah gizi ganda yang memiliki prevalensi tertinggi sangat kurus dan sangat gemuk (obesitas) pada remaja usia 13-15 tahun masing-masing 5,0\% dan $8,0 \%$ dan sangat kurus pada remaja usia 16-18 tahun yaitu 3,8\% (Kemenkes RI, 2013).

Berdasarkan data skrining status gizi tahun 2015 pada siswa-siswi Sekolah Menengah Atas dan sederajat seKabupaten Kulon Progo menunjukkan bahwa terdapat 245 siswa-siswi dengan status gizi gemuk dan sangat gemuk (obesitas), 336 kurus dan 54 siswa-siswi kurus sekali (Dinkes Kabupaten Kulon Progo, 2015). Masalah gizi pada masa remaja perlu mendapatkan perhatian khusus karena sangat berpengaruh pada pertumbuhan dan perkembangan tubuh serta dampaknya pada masalah gizi saat dewasa (Momongan et al., 2016).

Body image didefinisikan sebagai persepsi, pikiran dan perasaan seseorang tentang bentuk dan ukuran tubuhnya (As-Sa'edi et al., 2013). Body image negatif umumnya terjadi pada remaja (Contreras et al., 2015). Body image negatif merupakan gangguan serius yang dapat berpengaruh pada kesehatan mental, perilaku makan dan keterbatasan aktivitas fisik (Setyawati dan Setyowati, 2015).

Heinberg dan Thompson dalam Emilia (2009) mengemukakan tiga komponen dasar untuk mencegah timbulnya body image negatif pada remaja adalah melalui pendidikan tentang dampak membahayakan pengaturan berat badan yang tidak sehat, membantu mengatur penambahan berat badan yang sehat menggunakan prinsip gizi, diet dan aktivitas fisik serta mengembangkan keterampilan untuk melawan tekanan sosial dan budaya supaya kurus. Pendidikan dapat lebih efektif menggunakan media dibandingkan secara konvensional karena kemampuannya menyajikan peristiwa yang kompleks dan rumit menjadi lebih sistematik dan sederhana, meningkatkan daya tarik, perhatian dan sistematika pembelajaran (Eliana dan Solikhah, 2012).

Menurut Li et al (2012) bahwa media sosial dapat mempengaruhi kesehatan melalui beberapa cara seperti dukungan emosional, instrumental, informasi maupun terhadap penilaian diri. Facebook dapat memfasilitasi berbagi informasi yang berkaitan dengan sekolah dan belajar dan siswa-siswi dapat berdiskusi di facebook tentang topik yang sulit (Noh et al., 2013). Instagram merupakan media sosial lainnya yang dapat digunakan dalam proses pendidikan gizi. Kreativitas siswa-siswi dapat diukur dari hasil karya yang diunggah di instagram menurut segi, desain ataupun konten yang diunggah (Utami et al., 2015). Pendidikan gizi dengan media sosial memiliki segala macam kemudahan dalam mengaksesnya, tidak terbatas pada ruang dan waktu sehingga materi dapat disampaikan dan dipelajari kembali kapanpun dan dimanapun. Selain itu, media sosial telah menjadi bagian dalam kehidupan sehari-hari remaja dan pemanfaatannya dalam proses pendidikan gizi dapat menjadi lebih positif daripada hanya sekedar digunakan untuk eksistensi diri.

Tujuan penelitian adalah menganalisis pengaruh pendidikan gizi dengan media sosial terhadap persepsi body image remaja. Penelitian ini diharapkan dapat digunakan sebagai acuan dalam memberikan pendidikan gizi pada remaja sehingga dapat membentuk persepsi positif body image pada remaja.

\section{METODE PENELITIAN}

Jenis penelitian adalah Quasi Experimental Design dengan rancangan penelitian Nonequivalent Control Group. Populasi dalam penelitian ini adalah siswa-siswi kelas XI IPA SMAN 1 Wates (kelompok intervensi) dan SMAN 1 Lendah (kelompok kontrol) Kabupaten Kulon Progo.

Subjek penelitian untuk masing-masing kelompok sebanyak 42 remaja. Pengambilan subjek untuk setiap kelas dilakukan secara purposive sampling. Kriteria inklusi adalah siswasiswi kelas XI yang tercatat aktif di kelas XI IPA SMAN 1 Wates dan SMAN 1 Lendah, berusia 1617 tahun, tinggal bersama orang tua dan menandatangani informed consent oleh orang tua atau wali. Kriteria ekslusi adalah siswa-siswi yang tidak hadir saat pendidikan gizi dilakukan dan tidak mengikuti semua rangkaian kegiatan penelitian.

Varibel independent pendidikan gizi dengan media sosial dan variabel dependent adalah persepsi body image remaja. Persepsi body image remaja diukur dengan menggunakan Multidimensional Body Self Relation Questionnaire-Apperance Scale (MBSRQ-AS) yang dikembangkan oleh Thomas Cash pada tahun 1989. Pengukuran dilakukan sebelum dan setelah pendidikan gizi. Analisis data menggunakan uji Wilcoxon dengan SPSS.

\section{HASIL DAN PEMBAHASAN Karakteristik Umum Subjek Penelitian}


Tabel 1. Karateristik Umum Subjek Penelitian

\begin{tabular}{|c|c|c|c|c|}
\hline \multirow{2}{*}{ Karakteristik Umum } & \multicolumn{2}{|c|}{ Pendidikan Gizi dengan Media Sosial } & \multicolumn{2}{|c|}{ Kontrol } \\
\hline & $\mathrm{n}$ & $\%$ & $\mathrm{n}$ & $\%$ \\
\hline \multicolumn{5}{|l|}{ Jenis kelamin } \\
\hline Laki-laki & 21 & 50 & 21 & 50 \\
\hline Perempuan & 21 & 50 & 21 & 50 \\
\hline \multicolumn{5}{|l|}{ Usia } \\
\hline 16 tahun & 27 & 64.3 & 23 & 54.8 \\
\hline 17 tahun & 15 & 35.7 & 19 & 45.2 \\
\hline \multicolumn{5}{|l|}{ Pendidikan orang tua } \\
\hline \multicolumn{5}{|l|}{ Ayah } \\
\hline SD & 4 & 9.5 & 10 & 23.8 \\
\hline SMP & 3 & 7.1 & 4 & 9.5 \\
\hline SMA & 19 & 45.2 & 21 & 50 \\
\hline PT & 16 & 38.1 & 7 & 16.7 \\
\hline \multicolumn{5}{|l|}{ Ibu } \\
\hline SD & 5 & 11.9 & 14 & 33.3 \\
\hline SMP & 6 & 14.3 & 6 & 14.3 \\
\hline SMA & 16 & 38.1 & 16 & 38.1 \\
\hline PT & 15 & 35.7 & 6 & 14.3 \\
\hline \multicolumn{5}{|l|}{ Status gizi (IMT/U) } \\
\hline Obesitas & 2 & 4.8 & 3 & 7.1 \\
\hline Gemuk & 3 & 7.1 & 5 & 11.9 \\
\hline Normal & 33 & 78.6 & 31 & 73.8 \\
\hline Kurus & 4 & 9.5 & 3 & 7.1 \\
\hline Sangat kurus & 0 & 0 & 0 & 0 \\
\hline
\end{tabular}

Penelitian dilakukan pada 84 siswa-siswi lakilaki dan perempuan, masing-masing kelompok terdiri dari 42 remaja yaitu 21 siswa laki-laki dan 21 siswi perempuan. Usia subjek pada dua kelompok penelitian sebagian besar adalah 16 tahun dan pendidikan terakhir orang tua yaitu ayah dan ibu sebagian besar adalah SMA. Status gizi pada penelitian ini berdasarkan IMT/U. Hasil penelitian menunjukkan bahwa sebagian besar subjek penelitian pada kelompok pendidikan gizi dengan media sosial dan kelompok kontrol memiliki status gizi normal.

\section{Persepsi Body Image Subjek Penelitian Berdasar Status Gizi}

Tabel 2. Persepsi Body Image berdasarkan Status Gizi

\begin{tabular}{|c|c|c|c|c|c|c|c|c|c|}
\hline \multicolumn{2}{|c|}{ Persepsi Body Image } & \multicolumn{8}{|c|}{ Status Gizi } \\
\hline & & \multicolumn{2}{|c|}{ Kurus } & \multicolumn{2}{|c|}{ Normal } & \multicolumn{2}{|c|}{ Gemuk } & \multicolumn{2}{|c|}{ Obesitas } \\
\hline & & $\mathrm{n}$ & $\%$ & $\mathrm{n}$ & $\%$ & $\mathrm{n}$ & $\%$ & $\mathrm{n}$ & $\%$ \\
\hline \multicolumn{10}{|c|}{ Media sosial } \\
\hline \multirow[t]{2}{*}{ Pre } & $(+)$ & 0 & 0 & 20 & 47.6 & 0 & 0 & 0 & 0 \\
\hline & $(-)$ & 4 & 9.5 & 13 & 30.9 & 3 & 7.1 & 2 & 4.7 \\
\hline \multirow[t]{2}{*}{ Post } & $(+)$ & 1 & 2.4 & 26 & 62 & 0 & 0 & 0 & 0 \\
\hline & $(-)$ & 3 & 7.1 & 7 & 16.7 & 3 & 7.1 & 2 & 4.7 \\
\hline \multicolumn{10}{|c|}{ Kontrol } \\
\hline \multirow[t]{2}{*}{ Pre } & $(+)$ & 0 & 0 & 22 & 52.3 & 0 & 0 & 0 & 0 \\
\hline & $(-)$ & 3 & 7.1 & 10 & 23.8 & 4 & 9.5 & 3 & 7.1 \\
\hline \multirow[t]{2}{*}{ Post } & $(+)$ & 0 & 0 & 22 & 52.4 & 1 & 2.4 & 0 & 0 \\
\hline & $(-)$ & 3 & 7.1 & 10 & 23.8 & 3 & 7.1 & 3 & 7.1 \\
\hline
\end{tabular}

Hasil penelitian menunjukkan bahwa persepsi body image negatif tidak hanya terjadi pada remaja dengan status gizi kurus, gemuk dan sangat gemuk tetapi juga pada remaja dengan status gizi normal. 
Persepsi body image negatif pada remaja dengan status gizi normal pada kelompok media sosial sebelum intervensi adalah $30.9 \%$ dan setelah intervensi mengalami perubahan menjadi $16.7 \%$
Sedangkan pada kelompok kontrol tidak mengalami perubahan.

\section{Pengaruh Pendidikan Gizi dengan Media Sosial Terhadap Persepsi Body Image Remaja}

Tabel 3.Hasil Analisis Persepsi Body Image

\begin{tabular}{lccc}
\hline \multicolumn{1}{c}{ Persepsi Body Image } & n & \% & $p$ \\
\hline Pendidikan gizi dengan media sosial & & & \\
Pre & & & \\
$(+)$ & 20 & 47.6 & 0.008 \\
$(-)$ & 22 & 52.4 & \\
Post & & & \\
$(+)$ & 27 & 64.3 & \\
$(-)$ & 15 & 35.7 & \\
Kelompok kontrol & & & \\
Pre & & & \\
$(+)$ & 22 & 52.4 & \\
$(-)$ & 20 & 47.6 & \\
Post & & & \\
$(+)$ & 22 & 52.4 & \\
$(-)$ & 20 & 47.6 & \\
\hline
\end{tabular}

Berdasarkan Tabel 3 sebagian besar persepsi body image sebelum intervensi pada kelompok pendidikan gizi dengan media sosial adalah negatif sebanyak 52.4\% sedangkan pada kelompok kontrol positif sebanyak 52.4\%. Setelah dilakukan intervensi terjadi perubahan yaitu sebagian besar subjek penelitian memiliki persepsi body image positif sebesar $64.3 \%$ pada kelompok media sosial sedangkan pada kelompok kontrol tidak mengalami perubahan.

Berdasarkan hasil uji Wilcoxon diperoleh persepsi body image pada kelompok pendidikan gizi dengan media sosial $(p=0.008)$ sedangkan pada kelompok kontrol $(p=1.000)$. Hal ini menunjukkan bahwa ada pengaruh pendidikan gizi dengan media sosial terhadap persepsi body image.

Body image merupakan persepsi seseorang mengenai bentuk dan ukuran tubuhnya sendiri. Hal ini dipengaruhi oleh bentuk dan ukuran tubuh aktualnya, perasaannya tentang bentuk tubuhnya serta harapan terhadap bentuk dan ukuran tubuh yang diinginkannya dan bersifat dinamis (Calderon et al., 2017). Ketidakpuasan terhadap bentuk tubuh meningkat saat remaja dan menjadi sangat sensitif (Duarte et al., 2017). Beberapa remaja yang memiliki berat badan ideal bahkan masih merasa gemuk dan khawatir dengan perubahan berat badan dan penampilan tubuhnya (Mendonca et al., 2014). Persepsi body image negatif memiliki implikasi yang berbahaya bagi kesehatan psikologis dan fisik, seperti meningkatnya risiko rendah diri, depresi dan gangguan makan (Salci dan Ginis, 2017).
Hasil penelitian dengan uji Wilcoxon menunjukkan bahwa ada pengaruh pendidikan gizi dengan media sosial terhadap persepsi body image remaja ( $p=0.008$ ). Hasil penelitian tersebut sejalan dengan penelitian Nurrizka (2016), menunjukkan bahwa pengaruh positif media sosial terhadap perubahan gaya hidup pelajar SMA 04 Pontianak adalah sebagai sumber informasi, media komunikasi, media pendidikan dan hiburan, kemudahan bertransaksi dan berbisnis. Hasil penelitian Bahari (2013), menunjukkan bahwa promosi kesehatan melalui situs jejaring sosial yaitu facebook melalui wall post message di dinding facebook dapat merubah sikap remaja terhadap pencegahan penyakit HIV/AIDS.

Facebook memiliki potensi pendidikan dengan keuntungan mendapatkan informasi tentang pekerjaan rumah, materi dan ide. Berbagi konten teks dan multimedia dengan seluruh anggota kelas dan mengirim pengingat, pengumuman, atau berita kelas lainnya juga merupakan alasan lain mengapa siswa menggunakan facebook di bidang pendidikan (Erlin et al., 2015). Selain itu, situs media sosial berfungsi sebagai media promosi dan sumber informasi kesehatan yang berkembang saat ini, facebook dan instagram adalah media yang dapat digunakan untuk menuangkan ide kreatif melalui foto dan video menarik mengenai berbagai informasi kesehatan (Park et al., 2011).

Oleh karena itu, media sosial dapat digunakan sebagai media pendidikan yang berdampak positif terhadap kesehatan khususnya membentuk persepsi positif terhadap body image remaja. Media sosial 
mengajak siapa saja yang tertarik untuk berpartisipasi dengan memberi kontribusi dan feedback secara terbuka, memberi komentar dan membagi informasi dalam waktu yang cepat dan tak terbatas. Masa Remaja mampu menjadi masa perkembangan yang sangat potensial bagi segi fisik ataupun mental, sehingga melalui media sosial memungkinkan remaja untuk membentuk persepsi positif terhadap body image serta belajar lebih luas dengan memperdalam jaringan komunikasi dan informasi dari berbagai pihak.

Menurut Ansari et al (2010), jenis kelamin juga turut mempengaruhi persepsi body image. Jenis kelamin subjek penelitian pada kelompok pendidikan gizi dengan media sosial dan kelompok kontrol memiliki proporsi yang sama yaitu 21 remaja laki-laki dan 21 remaja perempuan. Perhatian terhadap bentuk tubuh terjadi pada lakilaki maupun perempuan misalnya remaja laki-laki memiliki perhatian terhadap bentuk tubuh lebih mengarah pada bentuk tubuh yang besar, berotot dan berisi sedangkan remaja perempuan lebih cemas terhadap perubahan berat badannya. Menurut Hernandez et al (2017), perempuan lebih sensitif terhadap body image dibandingkan lakilaki. Hasil penelitian Kantanista et al (2015) pada remaja 14-16 tahun di Polandia yang menunjukkan bahwa remaja perempuan lebih banyak memiliki persepsi body image negatif dibandingkan remaja laki-laki.

Menurut Ridha (2012) persepsi body image dipengaruhi oleh peran orang tua yang menjadikan individu lebih cepat terpengaruh. Berdasarkan hasil penelitian, pendidikan terakhir orang tua pada kelompok pendidikan gizi dengan media sosial dan kelompok kontrol baik ayah ataupun ibu sebagian besar adalah Sekolah Menengah Atas. Tingkat pendidikan seseorang akan berpengaruh dengan perkembangan potensi yang dimilikinya termasuk potensi emosional, pengetahuan, sikap dan keterampilan. Orang tua yang berpendidikan rendah dalam membimbing anak mengalami kendala - kendala karena keterbatasan ilmu pengetahuan sedangkan orang tua yang berpendidikan tinggi lebih sedikit mengalami kendala karena cukup ilmu yang dimiliki. Hasil penelitian menunjukkan bahwa semakin tinggi tingkat pendidikan terakhir orang tua maka semakin besar kemungkinan dapat membentuk persepsi positif body image pada remaja. Orang tua dengan pendidikan yang lebih tinggi dan pengetahuan yang cukup dapat menjelaskan dan memberi pendampingan dengan baik pada anak mengenai persepsi body image sehingga perilaku menyimpang terkait persepsi negatif body image dapat dihindari.
Penelitian ini menunjukkan bahwa persepsi negatif terhadap body image tidak hanya pada subjek penelitian dengan status gizi obesitas, gemuk dan kurus tetapi juga pada sujek penelitian dengan status gizi normal. Subjek penelitian dengan status gizi normal yang memilki persepsi negatif terhadap body image sebelum intervensi pada kelompok pendidikan gizi dengan media sosial sebanyak $30.9 \%$ sedangkan setelah intervensi $16.7 \%$.

Subjek penelitian tidak semuanya memiliki persepsi terhadap ukuran tubuh yang sepakat dengan status gizinya. Ketidaksepakatan ini dapat dilihat dari remaja yang mengalami overestimation yaitu mempersepsikan tubuhnya lebih besar dari keadaan sesungguhnya dan underestimation yaitu mempersepsikan tubuhnya lebih kecil dari keadaan yang sesungguhnya (Aprilianti, 2013). Hasil penelitian ini sejalan dengan Setyawati dan Setyowati (2015) pada remaja SMA yang menunjukkan bahwa masih terdapat remaja dengan status gizi normal yang tidak puas terhadap bentuk dan ukuran tubuhnya yaitu sebanyak $17.7 \%$. Persepsi body image negatif sangat umum terjadi pada masa remaja yang dapat menyebabkan depresi, rendahnya harga diri dan merupakan penyebab utama gangguan makan (Murray dan Rieger, 2011).

\section{SIMPULAN DAN SARAN Simpulan}

Berdasarkan hasil penelitian usia subjek penelitian sebagian besar adalah 16 tahun, pendidikan terakhir orang tua SMA dan status gizi IMT/U adalah normal. Selain itu, persepsi body image negatif juga terjadi pada remaja dengan status gizi normal. Kesimpulan terakhir adalah ada pengaruh pendidikan gizi dengan media sosial terhadap persepsi body image remaja $(p=0.008)$.

\section{Saran}

Sebaiknya remaja dapat memanfaatkan media sosial sebagai media untuk mendapatkan berbagai informasi kesehatan yang dapat membentuk sikap positif terhadap kesehatan khususnya persepsi positif terhadap body image.

\section{DAFTAR PUSTAKA}

Ansari, W., Clausen, S., Mabhala, A., Stock, C. 2010. How Do I Look? Body Image Perceptions among University Students from England and Denmark. Int. J. Environ. Res. Public Health, vol. 7, no. 2, hlm. 583-595.

Aprilianti, C. 2013. Persepsi terhadap Ukuran Tubuh dengan Status Gizi Remaja Putri di Kota Palangka Raya. Jurnal Info Kesehatan, vol. 11, no. 2, hlm. 478-490. 
As-Sa'edi, E., Sheerah, S., Al-Ayoubi, R., AlJehani, A., Tajaddin., W., Habeeb, H. 2013. Body Image Dissatisfaction: Prevalence and Relation to Body Mass Index among Female Medical Students in Taibah University, 2011. Journal of Taibah University Medical Sciences, vol. 8, no. 2, hlm. 126-133.

Bahari, D. 2013. Promosi Kesehatan Menggunakan Facebook dalam Meningkatkan Pengetahuan dan Sikap Remaja terhadap Pencegahan HIV/AIDS di SMA Negeri 1 Kutacane Kabupaten Aceh Tenggara. Tesis. Program Pascasarjana Universitas Gadjah Mada.

Calderon, C., Testal, J.,Garcelan, S., Perpina, C. 2017. Body Image and Adolescence: A Behavioral Impairment Model. Psychiatry Research, vol. 248, hlm. 121-126.

Cash, T. Body Images Research Consulting. Body Image Assessments: MBSRQ-AS. (http://www.bodyimages.com/assessments/mb srq.html), diakses 17 November 2016.

Christianti, D dan Khomsan, A. 2012. Asupan Zat Gizi dan Status Gizi pada Remaja Putri yang Sudah dan Belum Menstruasi. Jurnal Gizi dan Pangan, vol. 7, no. 3, hlm. 135-142.

Contreras, S., Sabiston, C., O'Loughlin, E., Belanger, M., O'Loughlin, J. 2015. Body Image Emotions, Perceptions and Cognitions Distinguish Physically Active and Inactive Smokers. Preventive Medicine Reports, vol. 2, hlm. 141-145.

Dinkes Kabupaten Kulon Progo. 2015. Rekapitulasi Hasil Penjaringan Kesehatan Peserta Didik Kabupaten Kulon Progo. Kulon Progo: Dinas Kesehatan Kabupaten Kulon Progo.

Duarte, C., Gouveia, J., Stubbs, R. 2017. The Prospective Associations Between Bullying Experiences, Body Image Shame and Disordered Eating in A Sample of Adolescent Girls. Personality and Individual Differences, vol. 116, hlm. 319-325.

Eliana, D dan Solikhah. 2012. Pengaruh Buku Saku Gizi terhadap Tingkat Pengetahuan Gizi pada Anak Kelas 5 Muhammadiyah Desa Wonokerto Kecamatan Turi Kabupaten Sleman Yogyakarta. Kemas, vol. 6, no. 2, hlm. 162-232.

Emilia, E. 2009. Pengetahuan, Sikap dan Praktek Gizi pada Remaja dan Implikasinya pada Sosialisasi Perilaku Hidup Sehat. Media Pendidikan, Gizi dan Kuliner, vol. 1, no. 1, hlm. 1-10.

Erlin., Fitri, T., Susandri. 2015. Using Social Networks: Facebook Usage at the Riau College Students. Procedia Computer Science, vol. 59, hlm. 559-566.
Erturgut, P dan Erturgut, R. 2010. An Analysis of Nutrition Level of Adolescent School Children with Respect to the Educational Levels and Child-Raising Attitudes of Their Parents. Procedia Social and Behavioral Sciences, vol. 2, no. 2, hlm. 1238-1243.

Faria, F., Gusmao, L., Faria, E., Gonçalves, V., Cecon, R., Franceschini, S., Priore, S. 2013. Polycystic Ovary Syndrome and Intervening Factors in Adolescents from 15 to 18 Years Old. Rev Assoc Med Bras, vol. 59, no. 4, hlm. 341-346.

Hernandez, V., Bojorquez, L., Romo, L., Unikel, C. 2017. 'You Have to Be Slim!'” Epiphanies: Body Image Construction in Middle-Aged Women. Revista Mexicana de Trastornos Alimentarios, vol. 8, hlm. 63-71.

Kantanista, A., Osinski, W., Borowiec, J., Tomczak, M., Zielinska, M. 2015. Body Image, Bmi, and Physical Activity in Girls and Boys Aged 14-16 Years. Body Image, vol. 15, hlm. 40-43.

Kemenkes RI. 2013. Riset Kesehatan Dasar (Riskesdas 2013). Jakarta: Badan Penelitian dan Pengembangan Kementrian Kesehatan Republik Indonesia. . 2013. Riset Kesehatan Dasar dalam Angka Provinsi Daerah Istimewa Yogyakarta 2013. Jakarta: Kementrian Kesehatan Republik Indonesia.

Li, J., Barnett, T., Goodman, E., Wasserman, R., Kemper, A. 2013. Approaches to Prevention and Management on Childhood Obesity: The Role of Social Networks and the Use of Social Media and Related Electronic Technologies. American Heart Association Journal, vol. 127, no. 2, hlm. 1-8.

Mendonca, K., Sousa, A., Carneiro, C., Nascente, F., Povoa, T., Souza, W., Jardim, T., Jardim, P. 2014. Does Nutritional Status Interfere with Adolescents' Body Image Perception?. Eating Behaviors, vol. 15, hlm. 509-512.

Momongan, M., Punuh, M., Kawatu, P. 2016. Hubungan antara Status Gizi dengan Prestasi Belajar Siswa SMA Negeri 7 Manado. Jurnal Ilmiah Farmasi, vol. 5, no. 2, hlm. 127-132.

Murray, K., Byrne, D., Rieger, E. 2011. Investigating Adolescent Stress and Body Image. Journal of Adolescence, vol. 34, hlm. 269-278.

Noh, N., Razak, S., Alias, N., Siraj, S., Jamil, M., Hussin, Z. 2013. Usage of Facebook: The Future Impact of Curriculum Implementation on Students in Malaysia. Procedia Social and Behavioral Sciences, vol. 103, hlm. 12611270. 
Nurrizka, A. 2016. Pengaruh Media Sosial terhadap Gaya Hidup Pelajar SMAN 04 Pontianak. Sociologique, vol. 4, no. 2, hlm. 114.

Park, H., Rogers, S., Stemmle, J. 2011. Health Organization Use of Facebook for Health Advertising and Promotion. Journal of Interactive Advertising, vol. 12, no.1, hlm. 6277.

Ridha, R. 2012. Hubungan antara Body Image dengan Penerimaan Diri pada Mahasiswa Aceh di Yogyakarta. Empathy, vol. 1, no. 1, hlm. 111-121.
Setyawati, V dan Setyowati, M. 2015. Karakter Gizi Remaja Putri Urban dan Rural di Provinsi Jawa Tengah. Kemas, vol. 11, no. 1, hlm. 4352.

UNICEF. 2012. Progress for Children: a Report Card in Adolescents. New York: 3 United Nation Plaza.

Utami, R., Probosari, R., Fatmawati, U. 2015. Pengaruh Model Pembelajaran Project Based Learning Berbantu Instagram terhadap Kemampuan Berpikir Kreatif Siswa Kelas X SMA Negeri 8 Surakarta. Bio-Pedagogi, vol. 4, no. 1, hlm. 46-52. 
Masitah R.,Pamungkasari E.P., Suminah / Kesehatan Terpadu 2(1) (2018) 